\title{
Pencegahan Penyebaran Wabah Covid 19 di Desa Midang Kabupaten Lombok Barat
}

\author{
Andre Rachmat Scabra', Varradila Azka Layalia ${ }^{2}$ \\ ${ }^{1}$ Program Studi Budidaya Perairan Universitas Mataram, ${ }^{2}$ Program Studi Akuntansi \\ Universitas Mataram
}

Alamat korespondensi : andrescabra@unram.ac.id

\begin{abstract}
ABSTRAK
Wabah Virus Corona pertama kali ditemukan di kota Wuhan, China pada akhir Desember 2019. Wabah tersebut sampai saat ini masih terus mengalami perkembangan yang menyebar ke seluruh Dunia. Desa Midang, Kecamatan Gunung Sari, Kabupaten Lombok Barat, merupakan salah satu lokasi yang terdampak pada penyebraan wabah virus corona (covid-19). Berdasarkan informasi dari warga setempat, telah terdapat beberapa kasus positif virus covid-19 yang menjangkiti warga di Desa Midang. Tujuan Kegiatan pengabdian kepada masyarakat ini adalah untuk mencegah terjadinya penyebaran wabah virus corona di Desa Midang Kabupaten Lombok Barat. Kegiatan pengabdian kepada masyarakat ini dijalankan dengan 2 metode, yaitu metode survey dan partisipasi aktif. Survey dilakukan untuk dapat memetakan programprogram yang dibutuhkan. Partisipasi aktif dilakukan dalam bentuk ikut serta dalam berbagai kegiatan yang berkaitan dengan upaya pencegahan penyebaran wabah virus corona. Waktu pelaksanaan kegiatan adalah 45 hari kerja. Kegiatan ini telah dilaksanakan dan menghasilkan berbagai program kerja, antara lain; sosialisasi tentang wabah covid-19 kepada masyarakat, pembuatan atau penyebaran pamplet mengenai gejala klinis dan cara pencegahan virus covid19, kampanye edukasi pencegahan covid-19, membuat pemetaan terkait dengan adanya ODP, PDP, maupun pasien yang terpapar covid-19, membagikan fasilitas protokol kesehatan berupa masker, pendampingan posyandu bagi anak-anak, bergotong royong bersih desa, penyemprotan disinfektan, dll. Kesimpulan kegiatan pengabdian kepada masyarakat ini adalah terkendalikannya penyebaran wabah covid-19 di Desa Midang melalaui berabagai program yang telah dijalankan.
\end{abstract}

Kata Kunci : desa midang, mitigasi bencana, pencegahan penyebaran covid-19

\section{PENDAHULUAN}

Wabah pandemi virus Corona atau yang disebut juga dengan Covid-19 (Corona Virus Disease 2019) pertama kali ditemukan di kota Wuhan, China pada akhir Desember 2019. Virus ini mempunyai sifat sangat mudah menular sehingga dalam waktu singkat infeksi menyebar ke seluruh dunia dan menimbulkan pandemi global (Wu et al., 2020). Virus Corona adalah sebuah keluarga virus yang bersifat zoonosis, yaitu dapat ditemukan melalaui penularan pada manusia dan hewan. Nadia (2020) menyatakan bahwa coronavirus (CoV) dapat menyebabkan penyakit mulai dari gejala ringan sampai berat. Setidaknya terdapat dua jenis coronavirus yang diketahui menyebabkan penyakit yang dapat menimbulkan gejala berat seperti Middle East Respiratory Syndrome (MERS-CoV) dan Severe Acute Respiratory Syndrome (SARS-CoV). 
Gejala yang ditimbulkan oleh penyakit ini adalah demam, batuk, dan napas yang pendek. The Center for Disease Control and Prevention (CDC) (2020) menyatakan bahwa pasien Virus Corona dapat mengalami gejala-gejala tersebut antara 2 sampai 14 hari setelah terpapar oleh virus. Zhang et al., (2020) menytakaan bahwa sebagian besar kasus infeksi corona virus memiliki tanda dan gejala seperti influensa seperti demam, batuk, pilek, pusing dan dalam kondisi berat bisa mengalami sesak napas yang berat. Anonim (2020) juga menyatakan bahwa tanda dan gejala umum infeksi coronavirus antara lain terjadinya gangguan pernapasan akut seperti demam, batuk dan sesak napas. Pada kasus yang berat, virus corona dapat menyebabkan pneumonia, sindrom pernapasan akut, gagal ginjal, dan bahkan kematian. Tingkat keparahan penyakit ini dapat dipengaruhi oleh daya tahan tubuh, usia dan penyakit yang telahada sebelumnya (komorbid), seperti hipertensi, DM, asma, dll.

Berbagai upaya dalam penanggulangan wabah virus corona telah dilakukan. Di Indonesia, bebrapa wilayah memberlakukan kebijakan Pembatasan Sosial Berskala Besar (PSBB) untuk menekan penyebaran virus ini. Cara terbaik yang disarankan untuk dilakukan dalam rangka melindungi diri adalah dengan menghindari kondisi atau tempat yang berpotensi menjadi agen pemaparan virus tersebut. World Health Organization (WHO) (2020) juga menyarankan agar selalu menggunakan masker apabila berada dalam kondisi yang berpotensi menjadi agen penyebaran virus. Asyary \& Veruswati (2020) menyatakan bahwa upaya yang bisa dilakukan dilakukan oleh semua pihak di dalam maupun di luar rumah, seperti social distancing, menggunakan masker ketika di luar rumah, sering melakukan cuci tangan, segera membersihkan diri setelah bepergian.

Virus ini menular dengan sangat cepat hanya dalam waktu beberapa bulan dan telah menyebar ke hampir semua negara, termasuk Indonesia. Virus ini dapat menyebar melalui tetesan cairan tubuh yang berasal dari mulut, hidung, atau mata. Tetes cairan tubuh dari orang yang terinfeksi virus ini dapat keluar melalaui bersin, batuk, atau melalui cara-cara lainnya. Penyebaran virus ini memiliki kemiripan dengan cara penularan penyakit flu. Desa Midang, Kecamatan Gunung Sari, Kabupaten Lombok Barat, merupakan salah satu lokasi yang terdampak pada penyebaran wabah virus corona (covid-19). Berdasarkan inforasi dari warga setempat, telah terdapat beberapa kasus positif virus covid-19 yang menjangkiti warga di Desa Midang.

Berdasarkan pemaparan tentang bahaya dan potensi penyebaran wabah virus corona, maka diperlukan kegiatan intensif dalam rangka pencegahan penyebaran wabah virus ini. Kegiatan pengabdan kepada masyarakat ini bertujuan untuk untuk mencegah terjadinya penyebaran wabah virus corona di Desa Midang Kabupaten Lombok Barat. Kegiatan ini diharapkan dapat memutus mata rantai penyebaran wabah Covid-19. Kegiatan ini dilakukan dengan aktif membantu Aparat Desa dan Satgas pencegahan Virus Covid-19 Desa Midang dalam mengedukasi, mencegah dan menanggulangi virus corona kepada masyarakat Desa Midang.

\section{METODE KEGIATAN}

Kegiatan pengabdian kepada masyarakat ini dilaksnakan melalaui berbagai tahapan, antara lain, tahap persiapan, dan pelaksanaan. Persiapan kegiatan meliputi survey lokasi dan perijinan pelaksanaan kegiatan ke perangkat desa terkait. Pelaksanaan kegiatan meliputi 
partisipasi aktif dalam menjalankan program-program yang telah disususun berdasarkan hasil survey pada saat persiapan. Lokasi pelaksanaan kegiatan adalah Desa Midang, Kabupaten Lombok Barat. Peta lokasi kegiatan dapat dilihat pada Gambar 1.

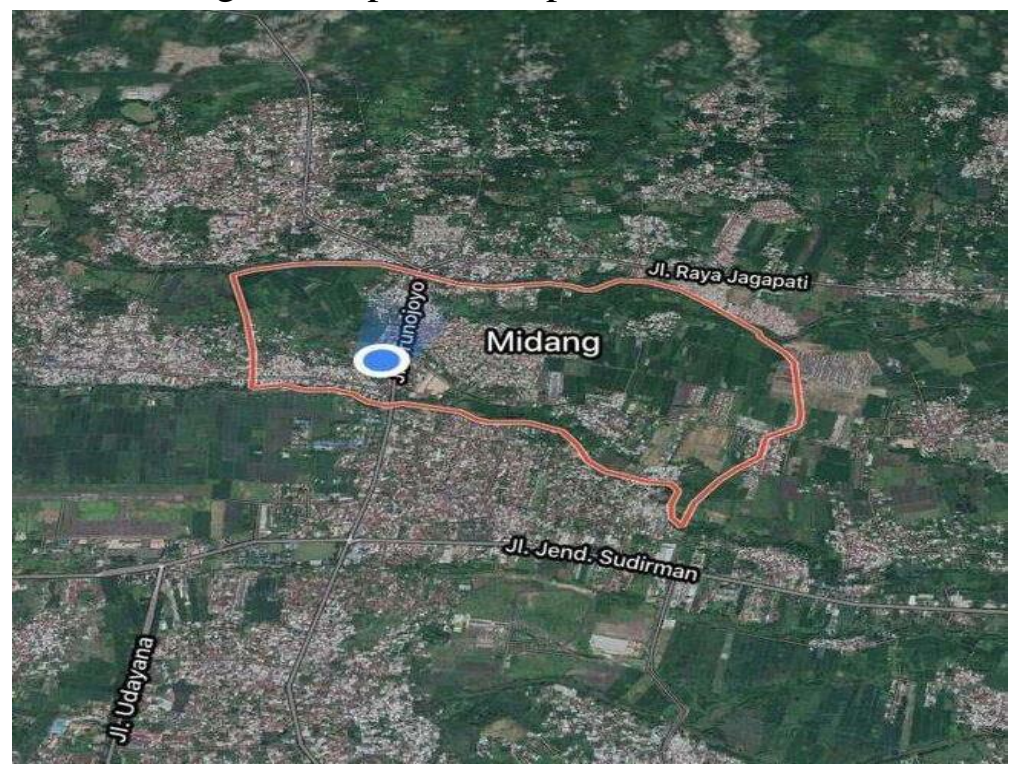

Gambar 1. Lokasi pelaksanaan kegiatan, Desa Midang, Kecamatan Gunung Sari, Kabupaten Lombok Barat

\section{Persiapan}

Langkah awal untuk menjalani kegiatan pengabdian kepada masyarakat ini adalah dengan mengurus perizinan melalaui kantor Desa Midang berupa surat izin instansi untuk melaksanakan kegiatan di Desa Midang. Perizinan diperlukan untuk keperluan administrasi kelembagaan yang menyatakan bahwa kegiatan yang dilakukan berbasis institusional yang terkontrol dengan baik. Perizinin kegiatan menjadi pintu masuk tim pelaksana kegiatan untuk turut serta dalam seluruh kegiatan yang dilakukan oleh pihak desa dalam rangka pencegahan penyebaran wabah virus corona.

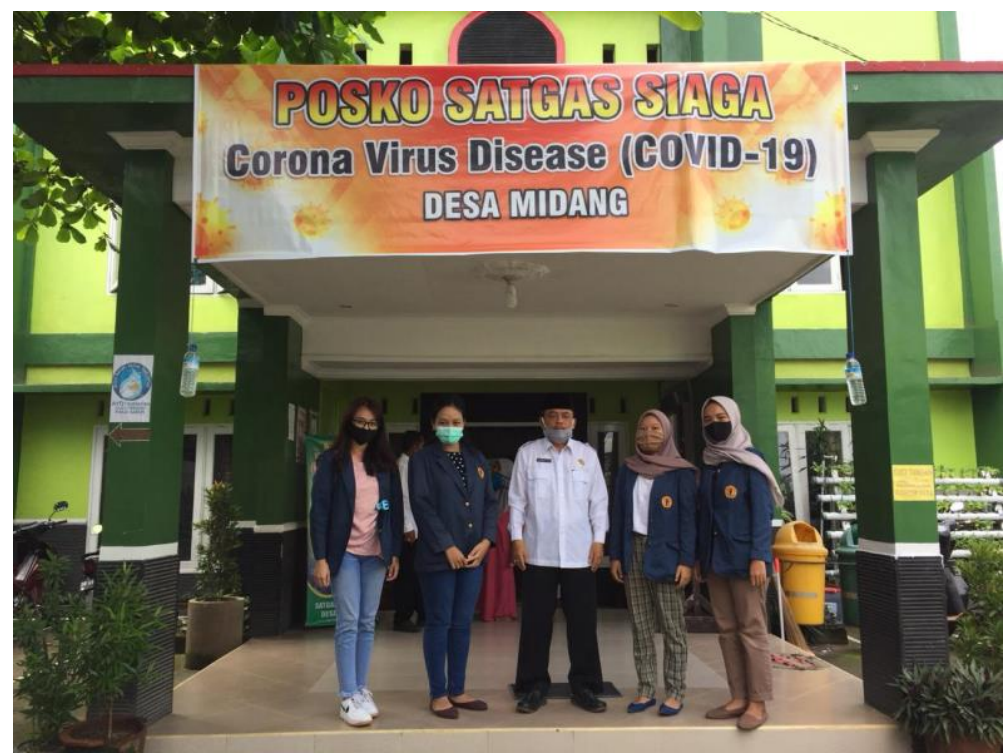

Gambar 2. Perizinan kegiatan pengabdian kepada masyarakat melalaui perangkat Desa Midang 


\section{Program Kerja}

Berdasarkan hasil survey dan koordinasi awal dengan perangkat Desa Midang, beberapa kegiatan yang telah dirumuskan untuk dijalanan adalah sebagai berikut :

1. Sosialisasi Pencegahan dan Penyebaran Virus Covid-19 Secara On-Line

2. Sosialisasi Pencegahan dan Penyebaran Virus Covid-19 Secara Off-Line

3. Melakukan pengotrolan akses keluar masuk desa

4. Pemberian paket bantuan bagi masyarakat terdampak

5. Melakukan penyemprotan desinfektan

6. Menggalakkan program rumah pangan mandiri

\section{HASIL DAN PEMBAHASAN}

\section{Sosialisasi Pencegahan dan Penyebaran Virus Covid-19 Secara On-Line}

Kegiatan sosialisasi pencegahan virus covid-19 dilakukan melalui platform sosial media berupa Whatsapp, Instagram dan Youtube. Whatsapp merupakan aplikasi media sosial yang sangat akrab dengan masyarakat. Pemilihan platform Instagram dilakukan karena media ini bisa diakses oleh seluruh lapisan usia mulai dari anak - anak hingga orang dewasa. Sosialisasi menggunakan Youtube juga dilakukan karena di zaman pandemic seperti ini banyak masyarakat yang mencari informasi melalui Youtube.

Pemilihan sosialisasi menggunakan sosial media karena di zaman canggih sekarang ini, orang - orang banyak mendapatkan informasi dan berita - berita terbaru, dibandingkan dengan menonton televisi, sosial media memberikan informasi lebih cepat dan akurat. Kegiatan ini dilakukan dengan memposting konten - konten yang terkait engan upaya pencegahan penyebaran wabah virus corona sebanyak 15 kali, yaitu 10 kali di Instagram, 1 kali di Whatsapp dan 4 kali di Youtube. Tidak ada kendala selama pelaksanaan kegiatan. Kelebihan dari sosialisasi ini adalah mudah diakses oleh seluruh masyarakat dan semua masyarakat mendapatkan informasi baru lebih cepat. Melalaui kegiatan ini, masyarakat diharapkan dapat mengetahui gejala klinis dan cara pencegahan virus Covid-19. Informasi yang disebarkan telah ditelaah sesuai dengan kaidah ilmiah sehingga masyarakat mendapatkan informasi yang akurat dan tidak simpang siur. 


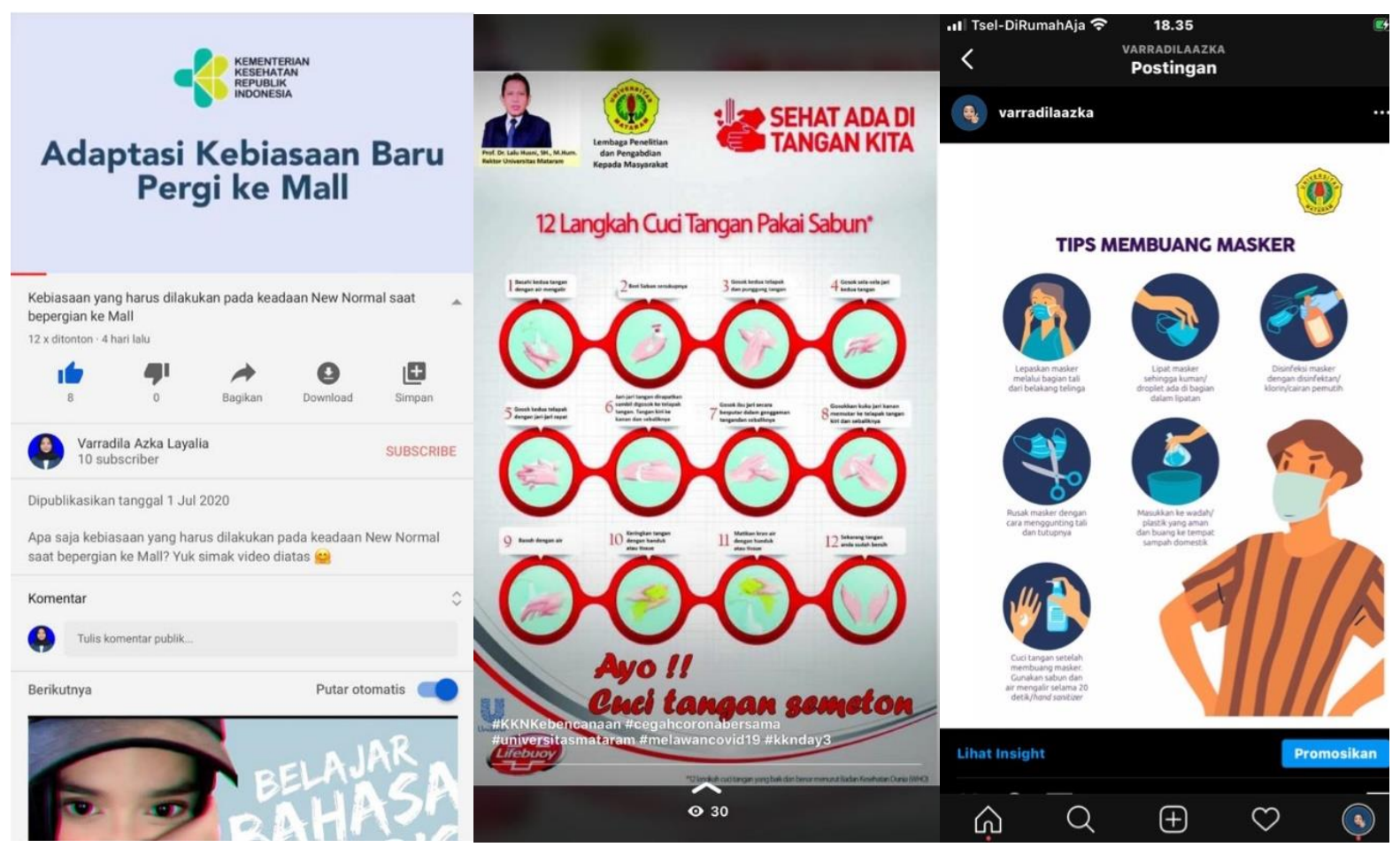

Gambar 3. Sosialisai pencegahan penyebaran wabah virus corona melalaui platform aplikasi WhatsApp, Instagram, dan Youtube

\section{Sosialisasi Pencegahan dan Penyebaran Virus Covid-19 Secara Off-Line}

Sosialisasi pencegahan penyebaran wabah covid-19 dilakukan secara langsung baik dengan tatap muka atau tidak. Diantara bentuk kegiatan ini adalah dengan mendatangi rumah warga secara door to door, penempelan pamphlet di berbagai lokasi strategis seperti pos kamling, musholla, toko sembako, dan rumah - rumah warga setempat, sosialisasi cara mencuci tangan yang baik dan benar kepada anak - anak warga desa. Kegiatan sosialisasi ini dilakukan sebanyak 11 kali dalam rentan waktu 45 hari kegiatan.

Sosialisasi dalam bentuk offline perlu dilakukan karena akan lebih mempermudah masyarakat dalam hal pemahaman terhadap materi sosialisasi. Masyraaat dpaat bertanya secara langsung terkait permasalahan yang dihadapi yang berkaitan dengan wabah covid-19. Pemilihan metode ini juga memberikan efek secara langsung bagi masyarakat yang ingin mendapatkan informasi. Melalaui sosialisasi ini, masyarakat menjadi lebih teredukasi sehingga dapat mengetahui mana saja yang boleh dan tidak boleh dilakukan selama pandemic Covid-19. 


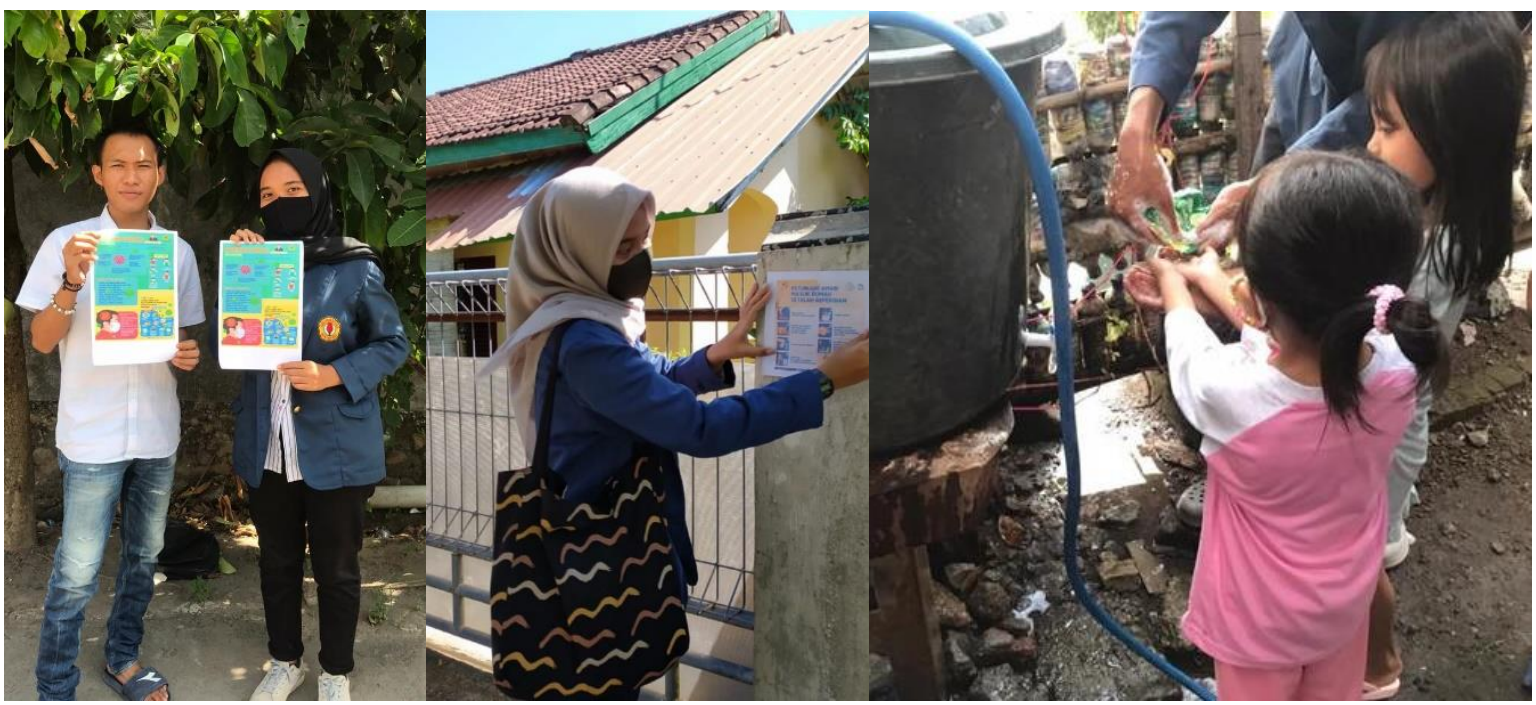

Gambar 4. Sosialisai pencegahan penyebaran wabah virus corona secara off-line

\section{Melakukan pengotrolan akses keluar masuk desa}

Sebagai bentuk kontroling pencegahan akses keluar dan masuknya wabah virus ini ke dalam area perkampungan, tim pelaksana kegiatan pengabdian kepada masyarakat melakukan kegiatan pengontrolan dan pengecekan suhu tubuh masyarakat yang menggunakan akses pintu keluar-masuk perkampungan. Kegiatan ini dilaksanakan berkolaborasi dengan Tim Satgas Covid-19 yang telah dibentuk oleh perangkat Desa. Kegiatan ini merupakan salah satu program rutin yang dilakukan oleh Tim Satgas Desa Midang untuk mencegah penularan virus Covid-19. Benyuk lain kegiatan ini adalah dengan melakukan penjagaan malam di sekitar Desa Midang untuk menghindari aktivitas masyarakat yang dapat menimbulkan berkumpulnya orang orang. Kendala yang dihadapi dalam pelaksanaan kegiatan ini adalah cuaca yang yang tidak menentu yang dapat berubah sewaktu-waktu.

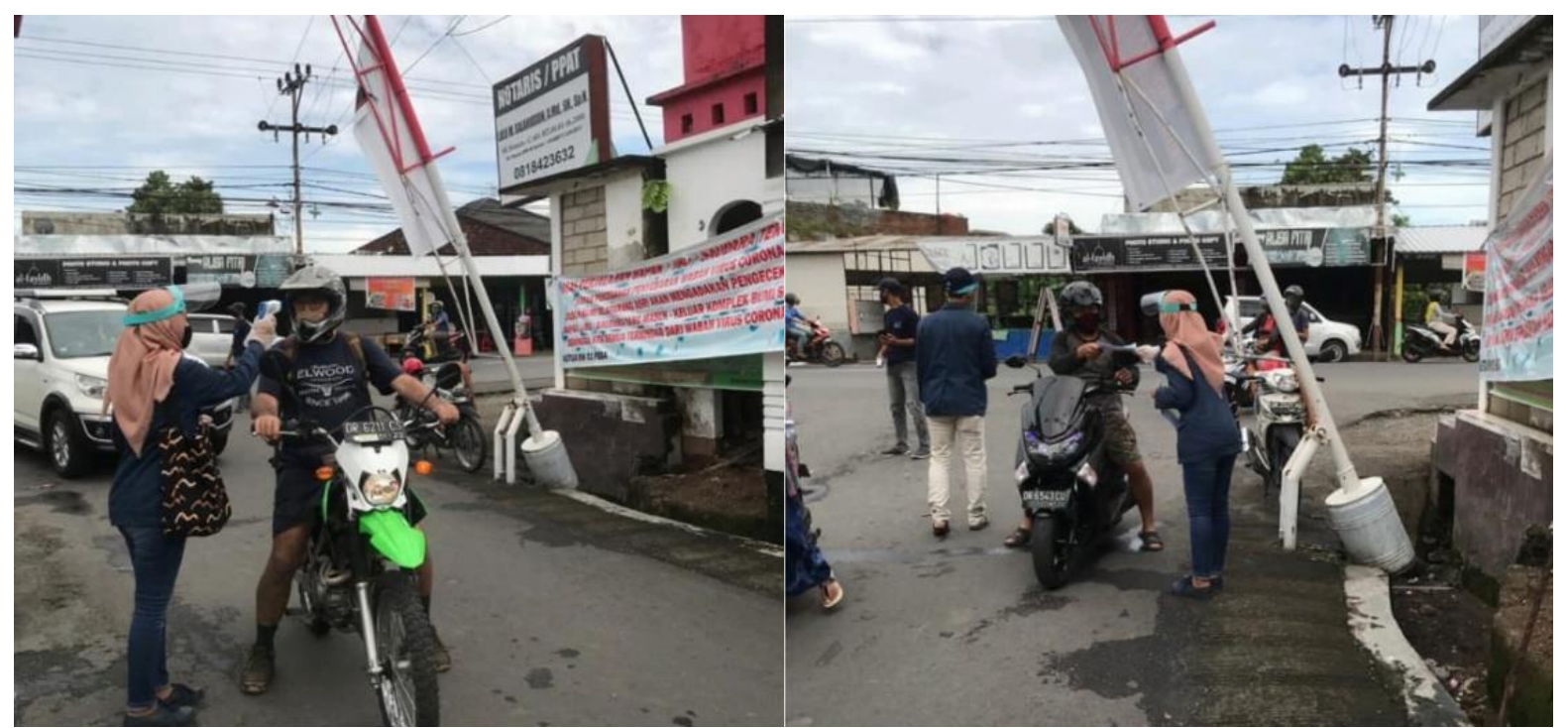

Gambar 5. Pengecekan suhu tubuh masyarakat yang menggunakan akses pintu keluar-masuk desa 


\section{Pemberian paket bantuan bagi masyarakat terdampak}

Salah satu kegiatan yang dilakukan oleh tim pelaksanan kegiatan pengadia kepada masyarakat yang bekerjasama dengan perangkat Desa Midang adalah membagikan bantuan kepada masyarakat yang terdampak covid-19. Bantuan tersebut berupa dana langsung dan paket sembako. Sumber dana kegiatan ini adalah kolaborasi antara pemerintah desa, kabupaten, dan provinsi, serta dari tim pelaksana kegiatan pengabdian kepada masyarakat.

Kegiatan ini sangat perlu untuk dilakukan karena pandemi covid-19 secara langsung berdampak terhadap kondisi perekonomian masyarakat. Sebagian masyarakat yang memiliki mata pencaharian berwirasuaha, mengalami permasalahan akses pasar yang disebabkan karena menurunnya aktifitas masyarakat di luar rumah. Penurunan aktifitas ini berkaitan dengan diberlakukannya aturan yang ketat bagi masyarakat yang berkegiatan di tempat umum.

Paket bantuan bagi masyarakat diberikan sebanyak 4 tahap. Penyaluran bantuan tahap I adalah Bantuan Langsung Tunai (BLT) tahap I yang berasal dari Pemerintah Daerah dan Pemerintah Kabupaten. BLT tahap I yang diberikan berupa uang tunai sebesar Rp600.000. Penyaluran bantuan tahap kedua adalah Bantuan Langsung Tunai - Dana Desa (BLT-DD) tahap II yang berasal dari dana desa. Bantuan ini berupa pemberian uang tunai sebesar Rp600.000. Penyaluran bantuan tahap III adalah Bantuan Sosial Tunai (BST) yang berasal dari Pemerintah Daerah Provinsi NTB. Bantuan tahap III ini berupa uang tunai sebesar Rp300.000. Penyaluran bantuan tahap IV adalah Jaminan Pengaman Sosial (JPS) yang berasal dari dari Pemerintah Kabupaten Lombok Barat. Bantuan tahap IV ini berupa bantuan sembako yang terdiri dari $1 \mathrm{~kg}$ gula, 1 liter minyak goreng, 1 buah masker, 1 tray telur dan 1 karung beras.

Kendala yang dihadapi dalam pelaksanaan kegiatan ini adalah banyaknya masyarakat yang datang untuk menerima bantuan, tidak mentaati aturan protokol yang telah ditetapkan. Selain itu, masyarakat juga kurang memperhatikan urusan administrasi, seperti misalnya membawa serta surat keterangan penerima bantuan yang telah digabikan sebelumnya. Meskipun begitu, paket bantuan tetap disalurkan secara merata ke seluruh warga masyarakat dan protokolo kesehatan tetap terjaga berkat kerja sama tim satgas covid dengan tim pelaksnaa kegiatan pengabdian kepada masyarakat.

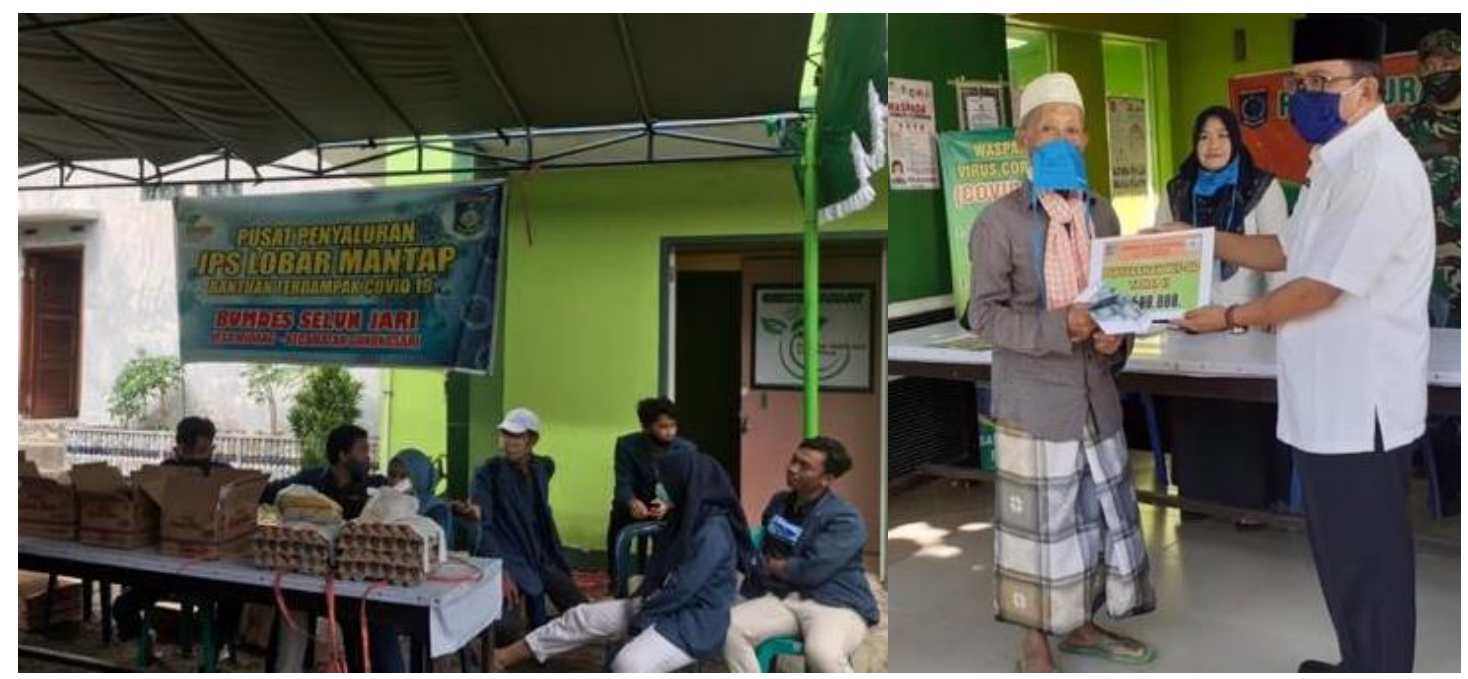

Gambar 6. Pemberian paket bantuan bagi masyarakat terdampak bencana pandemi 


\section{Melakukan penyemprotan desinfektan}

Disinfektan adalah cairan pembersih yang umumnya dibuat dari hidrogen peroksida, creosote, atau alkohol yang bertujuan untuk membunuh bakteri, virus, kuman, dan mikroorganisme berbahaya lainnya yang terdapat pada ruangan atau permukaan benda mati. Disinfeksi berarti mematikan atau menyingkirkan organisme yang dapat menyebabkan infeksi. Disinfeksi biasanya dilakukan dengan menggunakan zat - zat kimia seperti fenol, formaldehide, klor, iodium atau sublimat (Irianto, 2007).

Penyemprotan desinfektan merupakan salah satu kegiatan yang dilakukan oleh tim pelaksana pengabdian kepada masyarakat. Desinfektan disemprotkan pada berbagai tempat yang merupakan fasilitas umum seperti sekolah, kantor desa, dan masjid desa. Lokasi tersebut merupakan tempat yang sangat sering terjadi perkumpulan masa untuk berbagai keperluan. Lokasi sekolah yang merupakan tempat penyemprotan desinfektan adalah Sekolah Dasar Negeri 1 Midang dan Sekolah Dasar Negeri 2 Midang. Pada saat penyemprotan desinfektan sedang berlangsung, para siswa sekolah dasar di Desa Midang sedag menjalani pembelajaran secara Daring. Hal tersebut mempermudah tim pelaksana kegiatan untuk melakukan penyemprotan yang aman. Penyemprotan kantor desa dilakukan pada hari libur, yaitu pada hari Sabtu. Hal tersebut juga karena mempertimbangkan faktor keamanan. Masjid menjadi lokasi yang diminta untuk terus dilakukan penyemprotan desinfektan secara rutin. Hal tersebut karena masyarakat Desa Midang menginginkan melkuka ibadah rutin yang lebih aman.

Kendala yang dihadapi pada saat melakukan penyemprotan adalah jumlah fasillitas alat penyemprotan disinfektan yang hanya hany terdiri dari 1 unit. Hal tersebut menyebabkan kegiatan penyemprotan dilakukan secara bertahap untuk berbagai lokasi target. Dampaknya, penyemprotan menjadi lebih lama.

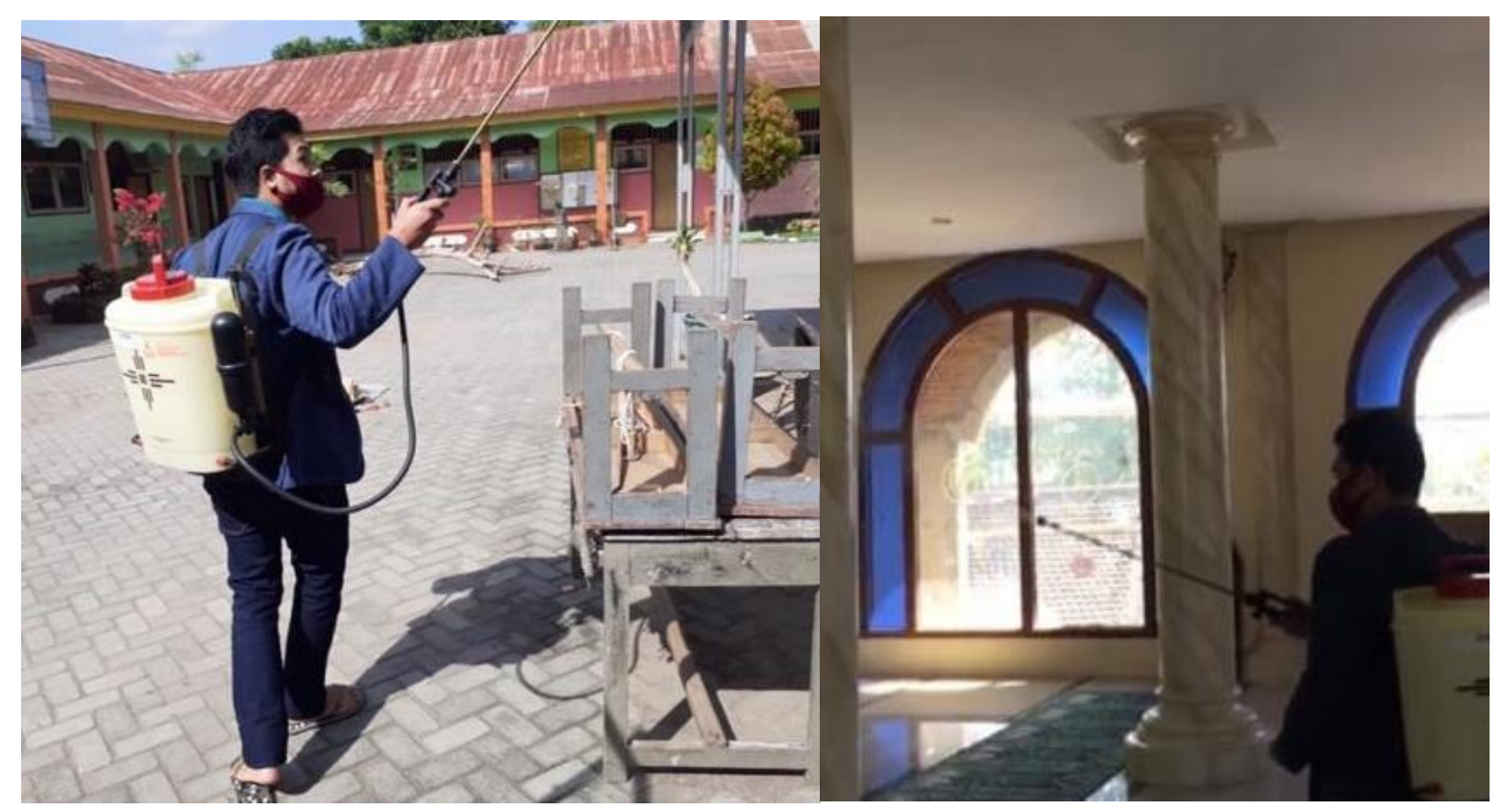

Gambar 7. Penyemprotan cairan desinfektan di tempat-tempat umum milik desa 


\section{Kesimpulan}

\section{KESIMPULAN DAN SARAN}

Kegiatan pencegahan penyebaran wabah covid -19 telah dilakukan pada Desa Midang abupaten Lombok Barat melalaui berbagai program kegiatan antara lain ; sosialisasi pencegahan dan penyebaran virus covid-19 secara on-line, sosialisasi pencegahan dan penyebaran virus covid-19 secara off-line, melakukan pengotrolan akses keluar masuk desa, pemberian paket bantuan bagi masyarakat terdampak, melakukan penyemprotan desinfektan, dan menggalakkan program rumah pangan mandiri.

\section{Saran}

Sebaiknya dilakukan kegiatan semacam ini secara kontinyue sampai wabah pandemi covid-a9 ini benar-benar dapat ditangani hingga tuntas.

\section{UCAPAN TERIMAKASIH}

Tim pelaksana kegiatan pengabdian kepada masyarakat mengucapkan terimakasih atas berbagai pihak yang terlibat di dalam pelaksanaan kegiatan, antara lain; mahasiswa dan mahasswa universitas mataram, dosen dan staf pegawai universitas mataram, lembaga penelitian dan pengabdian kepada masyarakat universitas mataram, perangkat pemerintahan dan masyarakat Desa Midang Kabupaten Lombok Barat, Pemerintah Kabupaten Lombok Barat, Pemerintah Provinsi Nusa Tenggara Barat.

\section{DAFTA PUSTAKA}

Anonim. (2020). Pedoman kesiapan menghadapi COVID-19. Jakarta : Kementerian Kesehatan Republik Indonesia.

Asyary, A., \& Veruswati, M. (2020). Sunlight exposure increased Covid-19 recovery rates: A study in the central pandemic area of Indonesia. Science of the Total Environment, 729, 139016. 1-4 https://doi.org/10.1016/j.scitotenv.2020.139016

Irianto, K. (2007). Mikrobiologi Menguak Dunia Mikroorganisme Jilid 1 2nd ed. N. Nurhayati, ed., Bandung: CV. Rama Widya.

Nadia, S. (2020). Kesiapan Kemenkes Dalam Menghadapi Outbreak Novel Coronavirus (2019nCoV). Jakarta (ID) : Ditjen Pencegahan Dan Pengendalian Penyakit Kementerian Kesehatan Republik Indonesia.

Wu, Y. C., Chen, C. S., \& Chan, Y. J. (2020). The outbreak of COVID-19: An overview. Journal of the Chinese Medical Association, 83(3), 217-220. https://doi.org/10.1097/JCMA.0000000000000270

Zhang, S., Xu, Y., Li, J., Wu, K., Wang, T., Su, X., \& Zhong, N. (2020). Symptomless multivariable apnea prediction index assesses adverse outcomes in patients with Corona Virus Disease 2019. Sleep Medicine, 75, 294-300. https://doi.org/10.1016/j.sleep.2020.08.031 